\title{
Liver Acinus Zone 2
}

National Cancer Institute

\section{Source}

National Cancer Institute. Liver Acinus Zone 2. NCI Thesaurus. Code C32994.

An area of hepatocytes between zone 1 and 3 in which the cells display properties intermediate to both neighboring zones. 